\title{
Estéticas da existência: Subjetivações sobre a moda
}

\author{
Lorena Pompei
}

ABDALA

\section{Resumo}

Como se dariam as propensões e noções de gosto? Pensando nas práticas de si é que se buscará, neste estudo, a transcendência do utilitarismo da moda para uma noção de subjetivação e experiência estética. Entendimento do posicionamento identitário legitimado pelas múltiplas dobras e territórios ocupados pelos sujeitos. Em maior ou menor grau possuímos objetivações e subjetivações de gosto relacionadas às práticas da aparência ou existência. Todos nós vemos e somos vistos, portanto de uma forma ou de outra é pouco provável um absoluto alheamento de si mesmo e dos outros. Somos artefatos visuais e portamos informações imagéticas. Negar a estética de si, no sentido foucaultiano, seria negar a própria existência, já que a constituição do Eu esta ligado à imagem do próprio corpo, segundo o "Estádio do Espelho" de Jacques Lacan. Assim, pensemos em corpos construídos por um discurso, corpos que se projetam pelas experiências estéticas como um meio de comunicação subjetiva com o mundo, corpos percebidos pela poética da obra aberta, que admitem um universo de formas perceptíveis e interpretações plurais que se complementam e geram novas formas de perceptos.

Palavras-chave: Moda; Estética; Subjetividade 